\title{
Hepatic portal venous gas after diving
}

\author{
Atsushi Jinno, ${ }^{1}$ Takanobu Hirosawa, ${ }^{2}$ Taro Shimizu ${ }^{2}$
}

1 Department of Emergency Medicine, Okinawa Yaeyama Hospital, Okinawa, Japan ${ }^{2}$ Department of Diagnostic and Generalist Medicine, Dokkyo Medical University, Tochigi, Japan

\section{Correspondence to} Dr Takanobu Hirosawa, t.hirosawa1983@gmail.com

Accepted 25 December 2017

\section{DESCRIPTION}

A 68-year-old man with diabetes and chronic kidney disease presented with severe epigastric pain and nausea $30 \mathrm{~min}$ after scuba diving in Ishigaki Island, southern part of Okinawa Prefec-

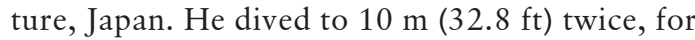
an hour each diving. The length of bottom time was unknown. The temperature of the water was $29.0^{\circ} \mathrm{C}\left(84.2^{\circ} \mathrm{F}\right)$. His vital signs were stable. On palpation of abdomen, there was no evidence of guarding and tenderness. There was also no rash. Venous blood gas showed a $\mathrm{pH}$ of 7.314 and lactate of $3.03 \mathrm{mmol} / \mathrm{L}$. Other laboratory values were unremarkable, including liver function tests and creatine kinase. An abdominal CT without contrast was performed because he had a history of allergic reaction to contrast agent. Abdominal CT demonstrated hepatic portal venous gas (HPVG, figures 1 and 2) and gases in the mesenteric vein (figure 2) and femoral vein (figure 3 ). There was no evidence of pneumatosis intestinalis. Based on the episode of scuba diving and the CT findings, he was diagnosed with decompression sickness (DCS). After admission, the patient was treated conservatively without hyperbaric chamber and successfully recovered. Two days after admission, a follow-up CT revealed that the HPVG and venous gases had completely disappeared and he was discharged without any symptoms.

HPVG is considered a clinically important finding because it is associated with high mortality rate. In most cases, urgent operative management is needed. HPVG is defined as peripheral gases within $2 \mathrm{~cm}$ beneath the liver capsule in CT. The peripheral gas distribution is related to the direction of blood flow into the

CrossMark

To cite: Jinno A, Hirosawa T, Shimizu T. BMJ Case Rep Published Online First: [please include Day Month Year]. doi:10.1136/bcr-2017223844

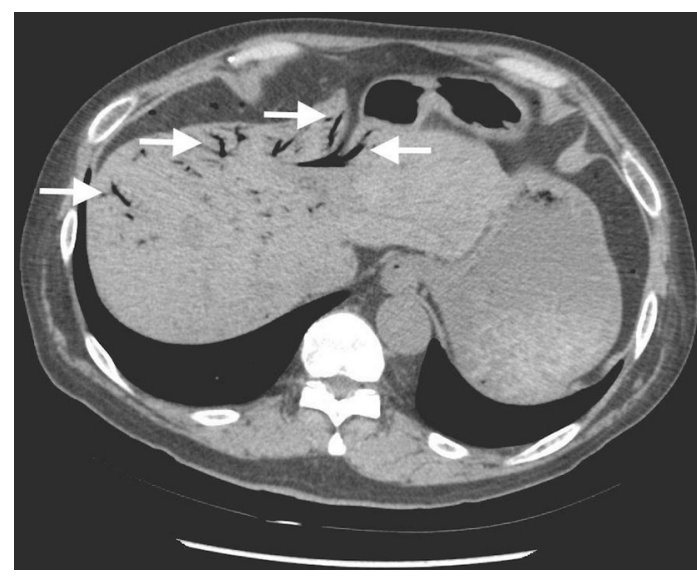

Figure 1 Non-contrast-enhanced CT (axial view) of the abdomen demonstrating hepatic portal venous gas (arrows).

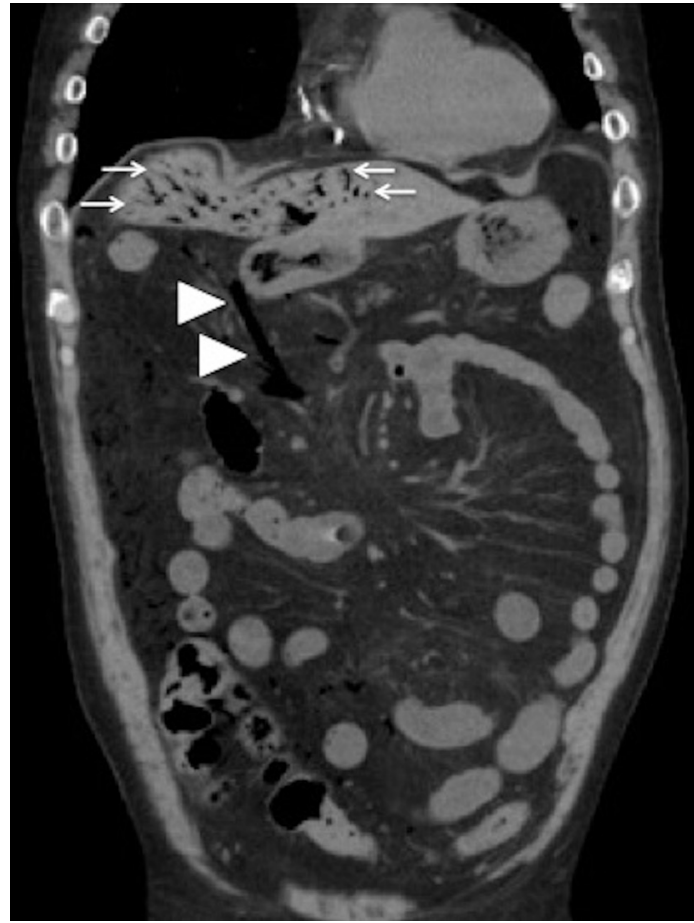

Figure 2 Non-contrast-enhanced CT (coronal view) of the abdomen demonstrating hepatic portal venous gas (arrows) and gases in the mesenteric vein (arrowheads).

liver. It is crucial to differentiate it from pneumobilia. The cause of HPVG ranges from fatal conditions such as bowel ischaemia to non-fatal causes such as diverticulitis and inflammatory bowel diseases. $^{1}$

Although the exact mechanism is unknown, DCS is caused by bubbles in blood or tissue after an improper decompression. ${ }^{2}$ In general, the diagnosis of DCS entirely depends on the clinical history and the manifestations. Some cases

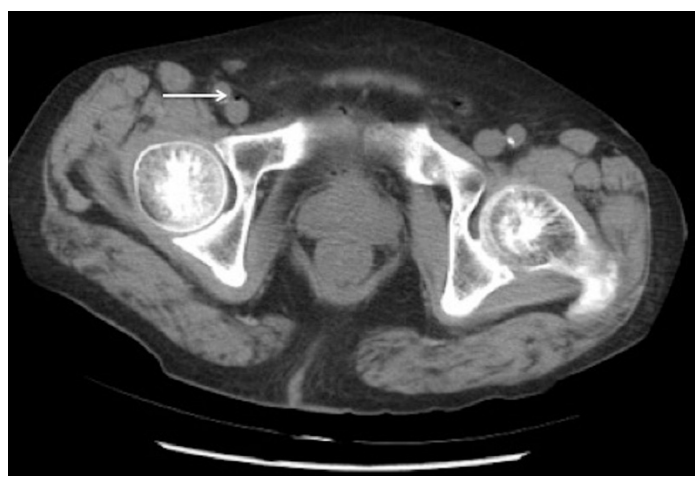

Figure 3 Non-contrast-enhanced CT (axial view) of the abdomen demonstrating gases in the right femoral vein (arrow). 


\section{Learning points}

The history of scuba diving is key in diagnosis of decompression sickness (DCS).

- DCS is one of those rare, but important differential diagnosis for abdominal pain, especially in scuba diving locations.

- Treatment for DCS is hyperbaric oxygen, but conservative therapy with close observation is another option.

reported skin mottling or cutis marmorata. Some cases also reported HPVG associated with DCS. ${ }^{3}$ HPVG is thought to arise when a diver ascends too quickly and air expands rapidly.

Treatment for DCS is hyperbaric oxygen. At first, we could not exclude other fatal conditions, such as bowel ischaemia. When hyperbaric oxygen therapy started, we could not perform his physical examination and follow-up laboratory tests frequently.
That was why close observation in intensive care unit had priority over immediate hyperbaric oxygen therapy at that time.

Contributors Both authors conceived the study concept and study design; performed compilation and synthesis of the data; participated in interpretation of the results and writing of the report and approved the final version. TH supervised the research project.

Competing interests None declared.

Patient consent Obtained.

Provenance and peer review Not commissioned; externally peer reviewed.

(c) BMJ Publishing Group Ltd (unless otherwise stated in the text of the article) 2018. All rights reserved. No commercial use is permitted unless otherwise expressly granted.

\section{REFERENCES}

1 Wiot JF, Felson B. Gas in the portal venous system. Am J Roentgenol Radium Ther Nucl Med 1961:86:103-7.

2 Vann RD, Butler FK, Mitchell SJ, et al. Decompression illness. Lancet 2011;377:153-64.

3 Sun Q, Gao G. Decompression Sickness. N Engl J Med 2017;377:1568.

Copyright 2017 BMJ Publishing Group. All rights reserved. For permission to reuse any of this content visit http://group.bmj.com/group/rights-licensing/permissions.

BMJ Case Report Fellows may re-use this article for personal use and teaching without any further permission.

Become a Fellow of BMJ Case Reports today and you can:

- Submit as many cases as you like

- Enjoy fast sympathetic peer review and rapid publication of accepted articles

- Access all the published articles

- Re-use any of the published material for personal use and teaching without further permission

For information on Institutional Fellowships contact consortiasales@bmjgroup.com

Visit casereports.bmj.com for more articles like this and to become a Fellow 